\title{
Quadriceps tendon autograft and platelet rich plasma injection for chronic Achilles tendon tears
}

\author{
Nicola Maffulli ${ }^{1,2,3}$ \\ ${ }^{1}$ Department of Musculoskeletal Disorders, Faculty of Medicine and Surgery, University of Salerno, Salerno, Italy; ${ }^{2}$ Queen Mary University of \\ London, Barts and the London School of Medicine and Dentistry, Centre for Sports and Exercise Medicine, Mile End Hospital, London E1 4DG, \\ England; ${ }^{3}$ Institute of Science and Technology in Medicine, Keele University School of Medicine, Stoke on Trent, England \\ Correspondence to: Nicola Maffulli. Department of Musculoskeletal Disorders, Faculty of Medicine and Surgery, University of Salerno, Fisciano, \\ Salerno, Italy. Email: n.maffulli@qmul.ac.uk. \\ Provenance and Peer Review: This article was commissioned by the editorial office of Annals of Translational Medicine. The article did not undergo \\ external peer review. \\ Comment on: Arriaza R, Arriaza Á, López-Vidriero E, et al. Quadriceps tendon autograft and platelet rich plasma injection to treat chronic Achilles \\ tears—a minimum two-year follow-up. Ann Transl Med 2019;7:746.
}

Submitted Mar 17, 2020. Accepted for publication Mar 31, 2020.

doi: $10.21037 / \mathrm{atm} .2020 .04 .32$

View this article at: http://dx.doi.org/10.21037/atm.2020.04.32

We are surgeons: it is ingrained in our DNA that we wish to leave our mark. We can do so in different ways: discovering a new condition, operating on more patients than anybody else, operating faster than our peers (though fast surgery is not necessarily good surgery), or describing new techniques or combining techniques in a way which had not been described before.

Arriaza et al. (1) built on the work of Besse et al. (2), who originally described the use of a bone-tendon graft from the extensor apparatus of the knee, to report their endeavour in the management of chronic tears of the Achilles tendon. Chronic tears of the Achilles tendon are increasingly common, are difficult to manage, the management algorithms are not evidence based, and the results of reconstructive procedures are often unsatisfactory.

In this manuscript, in addition to an ipsilateral bone-tendon autografts, the authors used a form of platelet rich plasma, namely plasma rich in growth factors, to augment their construct (3), perhaps unsurprisingly given how common the use of platelets derived devices is in their country.

I like to have alternatives in the management of my own patients with chronic tears of the Achilles tendon, and autografts are safe, cheap, and plentiful. Surely a graft harvested from the extensor apparatus of the knee satisfies these basic requirements. However, is it the best choice?

Regarding the extensor apparatus of the knee, anterior cruciate ligament reconstructive surgeons know that anterior knee pain after harvest is a scourge, and it figures prominently as the side effects and possible complications when we obtain informed consent from our patients. In addition, fracture of the patella is a well described complication following harvest of such grafts (4).

I have been trained in a system which engrained in me the mantra of 'Keep it simple for the simple orthopod', and I was also reminded that 'You need an intelligent guy to tackle complicated things, but the really bright ones make them simple'. In this respect, therefore, I must confess that I would not want to complicate my life using the extensor apparatus of the knee as a donor site for chronic Achilles tendon reconstruction. As Arriaza et al. acknowledge, two perfectly suitable local grafts are the tendon of peroneus brevis and the tendon of flexor hallucis longus. The classical paradigm was that a reconstruction of the Achilles tendon had to be performed so that the graft connects the proximal to the distal stump, thus anatomically restoring the continuity of the gastrosoleus-Achilles tendon-calcaneus complex. Recently, we have shown that this is not the case, and that the tendon of peroneus brevis or the tendon of flexor hallucis longus can each be transferred in a minimally invasive fashion into the posterior wall of the calcaneus without reconstructing the gap in an anatomical fashion, with excellent results (5). 
In gaps greater than $6 \mathrm{~cm}$, we harvest the tendon of semitendinosus from the popliteal fossa, we double it, and use it as a free graft to perform an anatomical reconstruction, again in a minimally invasive fashion (5). The tendon of semitendinosus is widely used for knee ligament reconstruction, its harvest carries little morbidity, and promptly regenerates (6).

We are left with the use of platelet rich plasma. Sánchez et al. used it in primary repair of Achilles tendon rupture, with impressive results (3). However, later larger studies have questioned this approach, and showed that the addition of PRP to the surgical management of Achilles tendon rupture does not appear to offer superior clinical and functional results $(7,8)$. Paradoxically, an Achilles tendon specific functional score was lower in the PRP group, suggesting a detrimental effect (8). A recent multicentre, parallel-group, participant- and outcome assessor-blinded randomised controlled trial comparing PRP with placebo in patients with an acute Achilles tendon tear treated nonsurgically showed that that PRP offers no patient benefit (9).

At the end of all this, it is legitimate to ask myself whether I would use a quadriceps tendon autograft for which (I) I need to work in a less than optimal position, as described by Arriaza et al.; (II) I would have to produce an extensive wound in a region notorious for its high rate of post-operative wound healing problems; (III) the length of the soft tissue component of the graft is limited. Also, regarding the use of the many formulations of platelet rich plasma, there is no doubt that some groups use this potentially powerful device extensively, and report impressive results. It is a pity, however, that these results vane into non-significance and null clinical relevance when appropriately planned, conducted and powered randomized controlled trials using clinically relevant validated outcome measures, performed by independent researchers with no conflicts of interest, are published.

\section{Acknowledgments}

Funding: None.

\section{Footnote}

Conflicts of Interest: The author has completed the ICMJE uniform disclosure form (available at http://dx.doi. org/10.21037/atm.2020.04.32). The author has no conflicts of interest to declare.
Ethical Statement: The author is accountable for all aspects of the work in ensuring that questions related to the accuracy or integrity of any part of the work are appropriately investigated and resolved.

Open Access Statement: This is an Open Access article distributed in accordance with the Creative Commons Attribution-NonCommercial-NoDerivs 4.0 International License (CC BY-NC-ND 4.0), which permits the noncommercial replication and distribution of the article with the strict proviso that no changes or edits are made and the original work is properly cited (including links to both the formal publication through the relevant DOI and the license). See: https://creativecommons.org/licenses/by-nc-nd/4.0/.

\section{References}

1. Arriaza R, Arriaza Á, López-Vidriero E, et al. Quadriceps tendon autograft and platelet rich plasma injection to treat chronic Achilles tears-a minimum two-year followup. Ann Transl Med 2019;7:746.

2. Besse JL, Lerat JL, Moyen B, et al. [Distal reconstruction of the Achilles tendon with a bonetendon graft from extensor system of the knee]. Rev Chir Orthop Reparatrice Appar Mot 1995;81:453-7.

3. Sánchez M, Anitua E, Azofra J, et al. Comparison of surgically repaired Achilles tendon tears using plateletrich fibrin matrices. Am J Sports Med 2007;35:245-51.

4. Fu FH, Rabuck SJ, West RV, et al. Patellar Fractures After the Harvest of a Quadriceps Tendon Autograft With a Bone Block: A Case Series. Orthop J Sports Med 2019;7:2325967119829051.

5. Maffulli N, Oliva F, Maffulli GD, et al. Surgical management of chronic Achilles tendon ruptures using less invasive techniques. Foot Ankle Surg 2018;24:164-70.

6. Papalia R, Franceschi F, D'Adamio S, et al. Hamstring Tendon Regeneration After Harvest for Anterior Cruciate Ligament Reconstruction: A Systematic Review. Arthroscopy 2015;31:1169-83.

7. De Carli A, Lanzetti RM, Ciompi A, et al. Can platelet-rich plasma have a role in Achilles tendon surgical repair? Knee Surg Sports Traumatol Arthrosc 2016;24:2231-7.

8. Schepull T, Kvist J, Norrman H, et al. Autologous platelets have no effect on the healing of human achilles tendon ruptures: a randomized single-blind study. Am J 
Sports Med 2011;39:38-47.

9. Alsousou J, Keene DJ, Harrison P, et al. Platelet-rich plasma injection for adults with acute Achilles tendon rupture: the PATH-2 RCT. Southampton (UK): NIHR Journals Library; 2019.

Cite this article as: Maffulli N. Quadriceps tendon autograft and platelet rich plasma injection for chronic Achilles tendon tears. Ann Transl Med 2020;8(13):809. doi: 10.21037/ atm.2020.04.32 